Imperial Subjects 
A book in the series

LATIN AMERICA OTHERWISE:

LANGUAGES, EMPIRES, NATIONS

Series editors:

Walter D. Mignolo, Duke University

Irene Silverblatt, Duke University

Sonia Saldivar-Hull, University of Texas, San Antonio

\section{ABOUT THE SERIES}

Latin America Otherwise: Languages, Empires, Nations is a critical series. It aims to explore the emergence and consequences of concepts used to define "Latin America" while at the same time exploring the broad interplay of political, economic, and cultural practices that have shaped Latin American worlds. Latin America, at the crossroads of competing imperial designs and local responses, has been construed as a geocultural and geopolitical entity since the nineteenth century. This series provides a starting point to redefine Latin America as a configuration of political, linguistic, cultural, and economic intersections that demands a continuous reappraisal of the role of the Americas in history, and of the ongoing process of globalization and the relocation of people and cultures that have characterized Latin America's experience. Latin America Otherwise: Languages, Empires, Nations is a forum that confronts established geocultural constructions, rethinks area studies and disciplinary boundaries, assesses convictions of the academy and of public policy, and correspondingly demands that the practices through which we produce knowledge and understanding about and from Latin America be subject to rigorous and critical scrutiny.

When can a subject be described as imperial and when as colonial? Imperial subjects seem to emerge from imperial identifications, such as the Spanish use of "Indian" to label the diverse people of Anahuac, Tawantinsuyu, and Abya-Yala. Descriptions of subjects as colonial imply new conditions of existence for people under imperial rule. In the sixteenth century, new identities emerged as traditional subjects, changing geo-political demarcations, and racism in the form of imperial hierarchies imposed over ethnic formations, came together.

This collection of essays offers a splendid map of identity formation at the intersection of imperial rule, colonial administration, the invention of "Indians," and the emergence of a new ethno-class, the Creole. The foreword by Irene Silverblatt and the introduction by Andrew B. Fisher and Matthew D. O'Hara lay the foundation for this exploration of the interconnected subjects of race and identity in colonial Latin America. 


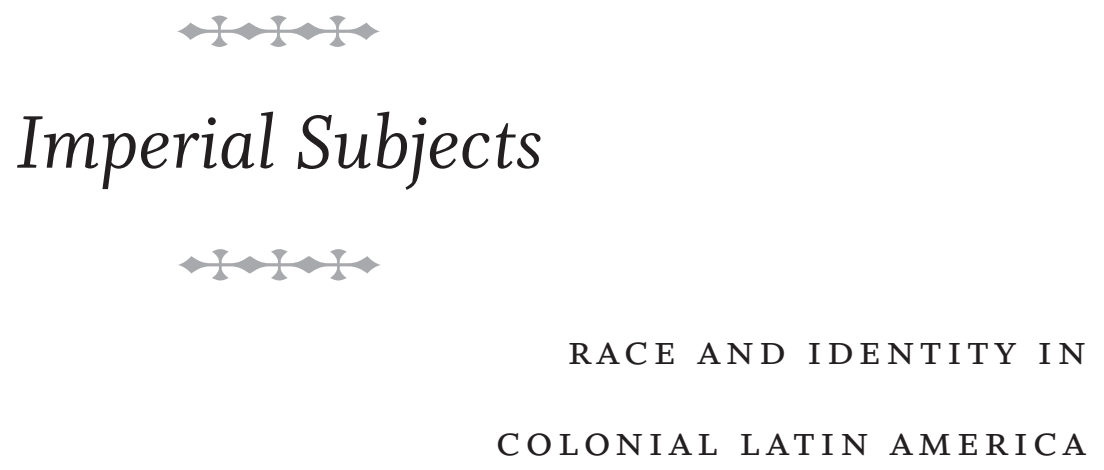

COLONIAL LATIN AMERICA

Andrew B. Fisher and Matthew D. O'Hara, eds.

Foreword by Irene Silverblatt

Duke University Press

Durham and London 2009 
(C) 2009 Duke University Press

All rights reserved

Printed in the United States of America on acid-free paper $\infty$

Designed by Heather Hensley

Typeset in Whitman by Keystone Typesetting, Inc.

Library of Congress Cataloging-in-Publication

Data appear on the last printed page of this book.

Duke University Press gratefully acknowledges the support of the Program for Cultural

Cooperation between Spain's Ministry of Culture and United States Universities, which provided funds toward the production of this book. 
A. B. F.

For Debbie and Gabriel

M. D. O.

For Sue, Maeve, Bridgid, and Farrin 
